\title{
Case report
}

\section{Synovial amyloid in chronic haemodialysis contains $\beta_{2}$ microglobulin}

\author{
F E BRUCKNER, ${ }^{1}$ MARGARET BURKE, ${ }^{2}$ R S PEREIRA ${ }^{3}$ A J EISINGER, ${ }^{4}$ \\ M BENDING, ${ }^{4} \mathrm{~J}$ KWAN ${ }^{4}$ A K OSMAN, ${ }^{1}$ AND B WATSON ${ }^{3}$ \\ From the ${ }^{1}$ Department of Rheumatology; St George's Hospital, London; the Departments of ${ }^{2}$ Histo- \\ pathology and ${ }^{3}$ Immunology, St George's Hospital Medical School, London; and the ${ }^{4}$ Renal Unit, St Helier \\ Hospital, Carshalton, Surrey
}

SUMMARY A case of amyloid arthropathy occurring in a patient receiving long term chronic $ᄋ$ haemodialysis treatment is reported. He was found to have raised serum $\beta_{2}$ microglobulin $\left(\beta_{2} M\right)$, and $\beta_{2} \mathrm{M}$ was detected in the synovial amyloid deposits.

One of the complications of long term chronic haemodialysis is amyloid arthropathy. ${ }^{1-3}$ We describe a patient, in whom $\beta_{2}$ microglobulin $\left(\beta_{2} \mathrm{M}\right)$ was found in the synovial amyloid deposits.

\section{Case report}

The patient was a 38 year old man who was in chronic renal failure from chronic glomerulonephritis of unknown cause. He had received regular haemodialysis treatment for 18 years using a cuprophane haemodialysis membrane. He had had four unsuccessful renal transplants during that time. A total parathyroidectomy was performed in 1982 . He had a left total hip replacement in 1980 and a right total hip replacement in 1981. Both carpal tunnels were decompressed in 1985 for carpal tunnel syndrome, but no histology was performed. Over the last 18 months he gradually developed pain, swelling, and stiffness of the shoulders, wrists, left thumb, knees, and left ankle.

Clinically there was swelling, pain, and restriction of all these joints with effusions in the knees and shoulders. There were no rheumatoid nodules or gouty tophi. The erythrocyte sedimentation rate was $10 \mathrm{~mm} / \mathrm{h}$, and tests for rheumatoid factor and antinuclear antibodies were negative. Serum uric acid, calcium, and phosphate were normal. Serum $\beta_{2}$ microglobulin on two occasions was 44 and 46 $\mathrm{mg} / \mathrm{l}$ (Pharmacia RIA - normal up to $3 \mathrm{mg} / \mathrm{l}$ ).

Accepted for publication 6 April 1987.

Correspondence to Dr F E Bruckner, Department of Rheumatology, St George's Hospital, Blackshaw Road, London SW17 0QT.
Synovial fluid from the right knee contained scanty $\vec{\theta}$ cells and no crystals. An $x$ ray examination showed a $\stackrel{\infty}{y}$ cyst $1 \mathrm{~cm}$ in diameter in the head of the right fibula suggestive of amyloid osteoarthropathy. ${ }^{4}$ At arthroscopy of the right knee, large fronds were seen and these areas were biopsied.

\section{Materials and methods}

METHODS

The tissue was fixed in $10 \%$ phosphate buffered formalin, processed, and embedded in paraffin wax. Sections $5 \mu \mathrm{m}$ thick were stained with Mayer's haematoxylin-eosin and with Congo red, the lattero with and without pretreatment of the sections with potassium permanganate. ${ }^{5}$

Immunohistochemical staining was performed on paraffin sections using the peroxidase-antiperoxidase method of Sternberger ${ }^{\circ}$ for polyclonal antibodies and with an indirect immunoperoxidase $\frac{}{2}$ method for monoclonal antibodies. ${ }^{7}$ The reaction was developed using diaminobenzidine and hydro- N gen peroxide. Polyclonal antibodies to $\beta_{2} \mathbf{M}_{N}$ (Dacopatts Ltd) were diluted 1:200 in TRIS buffered saline $(\mathrm{pH} 7 \cdot 4)$. Monoclonal antibodies to $x^{\mathrm{\omega}}$ and $\lambda$ light chains (Unipath Ltd) were used at $a<$ dilution of 1:1000. All sections were incubated with the primary antisera for one hour at room temperature.

CONTROLS

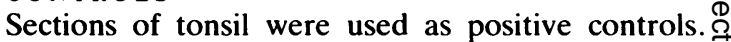
Specificity of staining was checked by omitting the $\stackrel{\mathbb{Q}}{\stackrel{Q}{2}}$ primary antibody in both test and control sections 


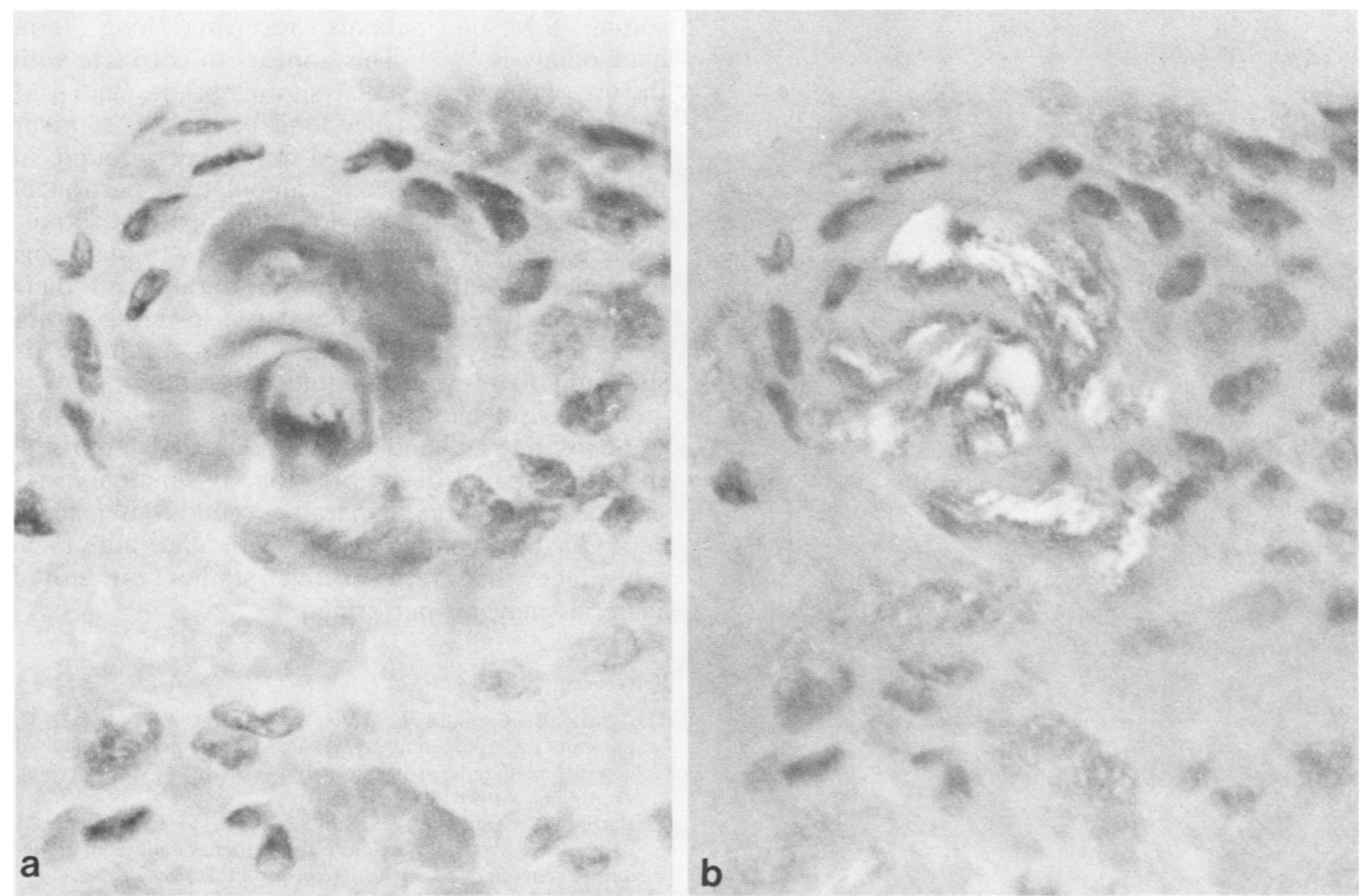

Fig. 1 Deposition of amyloid beneath the synovium (a) showing red-green birefringence on polarisation (b). This was reduced by prior treatment of the tissue with potassium permanganate. (Congo red).

and by screening cases of amyloid deposition in the kidney in myeloma and in rheumatoid arthritis, and also in Crohn's disease of the large intestine and medullary carcinoma of the thyroid.

\section{ELECTRON MICROSCOPY}

Tissue was fixed in $4 \%$ glutaraldehyde/l M cacodylate buffer. with secondary fixation in $1 \%$ osmium tetroxide, followed by dehydration and embedding in Araldite. Thin sections $(0 \cdot 5 \mu \mathrm{m})$ were examined on a Zeiss 109 transmission electron microscope.

\section{Results}

The synovium contained focal stromal amyloid, as demonstrated by congophilia with red-green birefringence under polarised light (Fig. 1). Immunohistochemical staining for $\beta_{2} \mathrm{M}$ was positive in the test section (Fig. 2) and negative in all the other cases of amyloid. Immunoglobulin light chains were not detected in any of the specimens. Amyloid deposition was confirmed ultrastructurally by the presence of rigid non-branching fibrils $10-12 \mathrm{~nm}$ in diameter (Fig. 3).

\section{Discussion}

Our findings, using immunohistochemical staining. confirm those of Gejyo et $a l^{*}$ and Gorevic et al, " who isolated $\beta_{2} \mathrm{M}$ biochemically from amyloid in their two patients with amyloid arthropathy complicating chronic haemodialysis. Similar findings have also been reported by Casey et $a l^{10}$ in a further two patients receiving long term haemodialysis who developed $\beta_{2} \mathrm{M}$-rich amyloid deposits in bone. Ultrastructurally, both Gorevic et $a l^{9}$ and Casey et $a l^{10}$ observed that the amyloid fibrils had an unusual curvilinear configuration. This was not seen in our case, however, which conforms to the conventional ultrastructural appearances of amyloid, described as 'fine, non-branching fibrils 8-10 nm in diameter and up to $1 \mu \mathrm{m}$ in length, arranged randomly'. "Further evidence for the amyloidogenic properties of $\beta_{2} \mathrm{M}$ has been illustrated by the in vitro formation of amyloid from intact $\beta_{2} \mathrm{M},{ }^{12}$ which perhaps is not surprising in view of its biochemical similarity to the constant regions of immunoglobulin light and heavy chains. $^{13}$

There have been several reports of raised levels of 


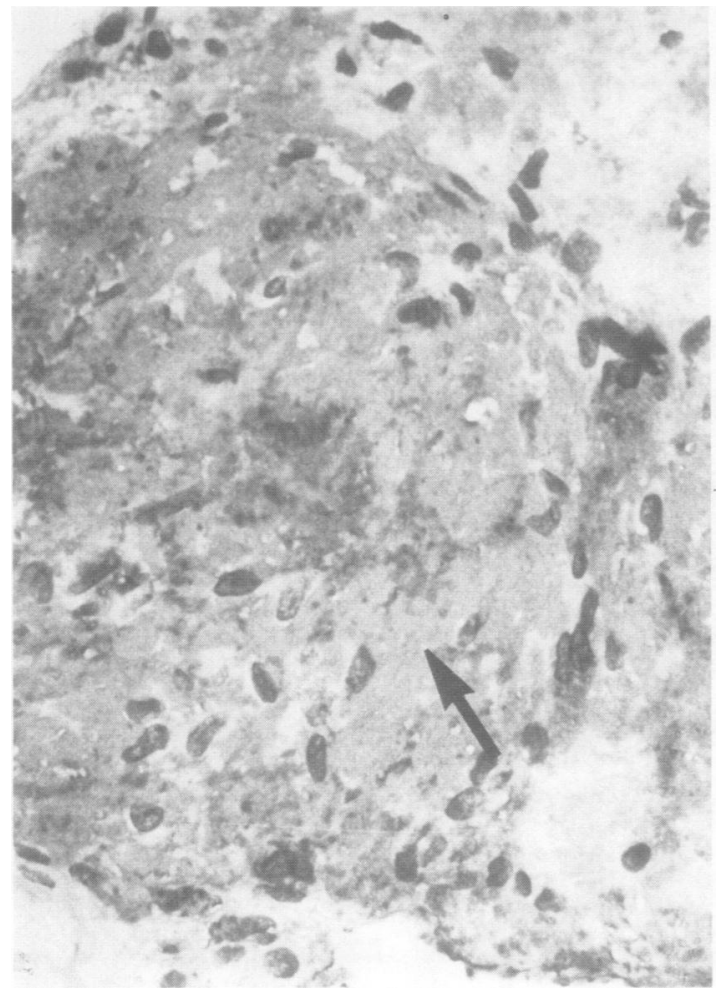

Fig. 2 Immunoperoxidase staining of synovium showing that the stromal deposit of amyloid contains $\beta_{2}$ microglobulin (arrow), which is not present in adjacent tissue. (Peroxidase-antiperoxidase). serum $\beta_{2} \mathrm{M}$ in patients receiving long term $\frac{\text { ? }}{\cos }$ haemodialysis. ${ }^{+15-7}$ This appears to correlate with $\Rightarrow$

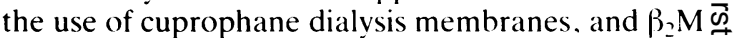
levels fall during polyacrylonitrile dialysis. Similaro high levels of serum $\beta_{2} \mathrm{M}$ have been found in $\underline{\bar{E}}$ patients receiving chronic ambulatory peritoneal $\frac{\bar{\sigma}}{\bar{Q}}$ dialysis treatment. ${ }^{17}$ Amyloid arthropathy has not. $\stackrel{\mathbb{\complement}}{\varrho}$ to date, been reported in these cases. though this may merely reflect the shorter duration of their treatment. It remains to be seen if lowering serum. $\beta_{2} \mathrm{M}$ alone, by changing the dialysis technique. is sufficient to prevent amvloid deposition.

We have demonstrated $\beta_{2} \mathrm{M}$ in synovial amyloid as opposed to amyloid in tissues removed at the time of carpal tunnel decompression. Its immunohistochemical detection in paraffin sections is simple. reproducible, and specific, with the additional ${ }_{\AA}^{\infty}$ advantage that retrospective studies on storedo material may be performed.

\section{References}

I Charra B. Calmard E. Lzan M. Terrat J C. Vanel T. Laurent G. Carpal tunnel syndrome, shoulder pain and amyloid $\vec{\oplus}$ deposits in long-term hacmodialysis patients. Proc Eur Dial Transplant Assoc 1984: 21: 291-5.

2 Bardin T. Kuntz D. Zingraff J. Voisin M C. Zelmar A. Lansman J. Synovial amvloidosis in patients undergoing longterm haemodialysis. Arthritis Rheum 1985: 28: 1052-8.

3 Muñoz-Gómez J. Bergadá-Barado E. Gómez-Pérez R. et al. $\bar{O}$ Amyloid arthropathy in patients undergoing periodical ڤֶ haemodialysis for chronic renal failure: a new complication. $\mathbb{D}$ Ann Rheum Dis 1985: 44: 729-33.

+ Vandenbroucke J M. Jadoul M. Maldague B. Huax J P. $\overline{\bar{O}}$ Noel H. van Ypersele De Strihou C. Possible role of dialysis

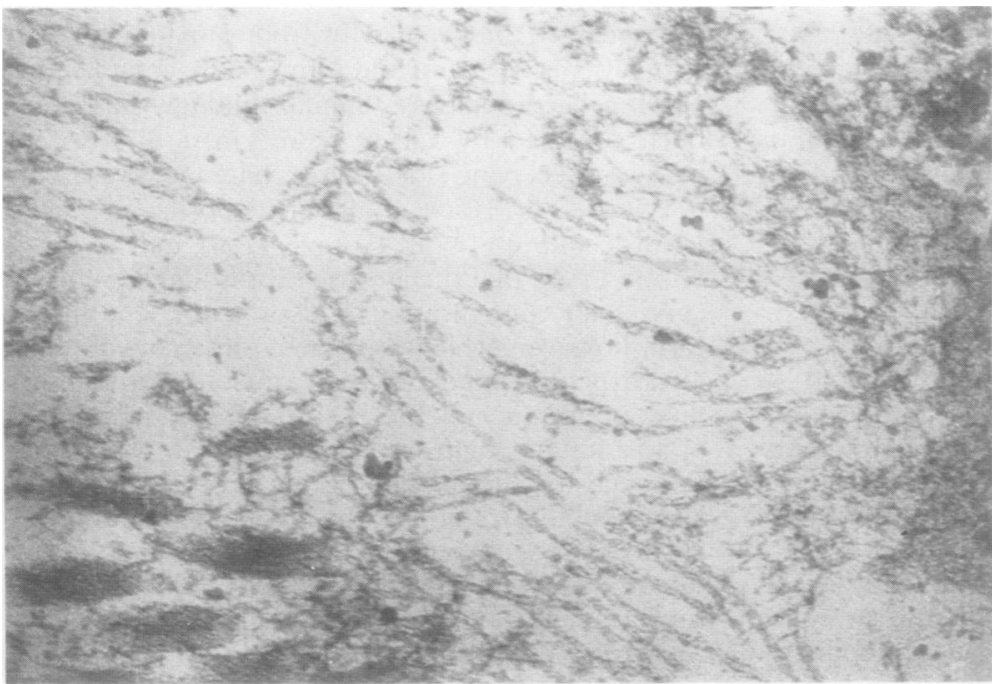

Fig. 3 Ultrastructual appearances of amyloid showing straight non-branching fibrils approximately $10-12 \mathrm{~nm}$ in diameter. 
membrane characteristics in amyloid osteoarthropathy. Lancet 1986; i: $1210-1$.

5 Wright J R, Calkins E, Humphrey R L. Potassium permanganate reaction in amyloidosis. Lab Invest 1977; 36: 274-81.

6 Sternberger L A. Hardy P H Jr, Cuculis J J. Ineyer H G. The unlabelled antibody-enzyme method of immunohistochemistry. J Histochem Cytochem 1970; 18: 315-33.

7 Nakane P K. Kawasi A. Peroxidase-labelled antibody: a new method of conjugation. J Histochem Cytochem 1974; 22: 1084-91.

8 Gejyo F, Yamada T, Odani S, et al. A new form of amyloid protein associated with chronic haemodialysis was identified as $\beta_{2}$ microglobulin. Biochem Biophys Res Commun 1985; 129: 701-6.

9 Gorevic P D, Casey T T, Stone W J, Di Raimondo C R, Prelli F C. Frangione B. Beta-2 microglobulin is an amyloidogenic protein in man. $J$ Clin Invest 1985; 76: 2425-9.

10 Casey T T, Stone W J, Di Raimondo C R, et al. Tumoural amyloidosis of bone of $\beta_{2}$-microglobulin origin in association with long-term haemodialysis. Hum Pathol 1986; 17: 731-8.
11 Cohen A S. Calkins E. A light and electronmicroscopic study of human and experimental amyloid disease of the kidneys. Arthritis Rheum 1959; 2: 70.

12 Connors L H, Shirahama T, Skinner M, Fenves A, Cohen A S. In vitro formation of amyloid fibrils from intact $\beta_{2}$ microglobulin. Biochem Biophys Res Commun 1985; 131: 1063-8.

13 Messner R P. $\beta_{2}$-microglobulin-an old molecule assumes a new look. J Lab Clin Med 1984: 104: 141-5.

14 Peterson P A. Cunningham B A. Berggard I. Edelman G M. $\beta_{2}$-microglobulin-a free immunoglobulin domain. Proc Natl Acad Sci USA 1972; 69: 1697-701.

15 Hauglustaine D. Waer M. Michielson P, Goebels J. Vandeputte $M$. Haemodialysis membranes, serum $\beta_{2}$-microglobulin, and dialysis amyloidosis. Lancet 1968; i: 1211-2.

16 Chanard J, Lavaud S, Toupance O. Melin J P, Gillery P, Revillard J P. $\beta_{2}$-microglobulin associated amyloidosis in chronic haemodialysis patients. Lancet 1986; i: 1212.

17 Ballardie F W, Kerr D N S. Tennent G, Pepys M B. Haemodialysis versus CAPD: equal predisposition to amyloidosis? Lancet 1986; i: 795-6. 